\title{
Concentrations of Trace Elements in Daily Life Water Consumed in Angono, Rizal, Philippines
}

\author{
Seiji Maruyama, ${ }^{1}$ Hisaaki Kato, ${ }^{2}$ Gilbert J. Merino, ${ }^{3}$ Takafumi Hirata ${ }^{4,5}$ and Noel R. Juban ${ }^{6}$ \\ ${ }^{1}$ Kyoto Fission-Track Co., Ltd., Kyoto, Japan \\ ${ }^{2}$ The Institute of Scientific and Industrial Research, Osaka University, Osaka, Japan \\ ${ }^{3}$ Municipal Health Office, Angono, Rizal, Philippines \\ ${ }^{4}$ Department of Geology and Mineralogy, Faculty of Science, Kyoto University, Kyoto, Japan \\ ${ }^{5}$ Geochemical Research Center, Graduate School of Science, The University of Tokyo, Tokyo, Japan \\ ${ }^{6}$ Department of Clinical Epidemiology, College of Medicine, University of the Philippines Manila
}

\begin{abstract}
Objective. The present study aims to determine the concentrations of seven trace elements [chromium $(\mathrm{Cr})$, arsenic (As), cadmium (Cd), cesium $(\mathrm{Cs})$, lead $(\mathrm{Pb})$, thorium $(\mathrm{Th})$, and uranium $(\mathrm{U})$ ] in tap, well, spring, river, and lake waters in the town of Angono, Rizal in the Philippines, consumed for drinking, cooking, bathing, and washing. In the town of Angono, both of the tap and purified tap waters produced in the refilling station are consumed as the water for drinking.

Methods. Water samples from six unpurified tap, six purified taps, 10 wells, two springs, two rivers, and one lake water were obtained in October 2015. Samples were analyzed using solution nebulization inductively coupled plasma mass spectrometry. Results were evaluated for health risks of the trace elements in the water samples using WHO guideline values. The provisional WHO guideline values are as follows: Cr: $50 \mu \mathrm{g} / \mathrm{L}, \mathrm{As}: 10 \mu \mathrm{g} / \mathrm{L}$, $\mathrm{Cd}: 3 \mu \mathrm{g} / \mathrm{L}, \mathrm{Pb}: 10 \mu \mathrm{g} / \mathrm{L}$, and U: $30 \mu \mathrm{g} / \mathrm{L}$. That of Cs has not been proposed yet. The WHO guideline value for the naturally occurring radioactive isotope ${ }^{232} \mathrm{Th}$ in drinking water is $1 \mathrm{~Bq} / \mathrm{L}$, which is equivalent to $250 \mu \mathrm{g} / \mathrm{L}$.
\end{abstract}

Results. The concentrations of the trace elements in the tap water samples were $<0.5 \%$ of the WHO guideline values, except $\mathrm{Cs}$ and $\mathrm{Cd}$, with those of $\mathrm{Cd}$ being $~ 9 \%$ of the WHO guideline value. Purified tap waters contained the seven trace elements in lower concentrations, with the exception of $\mathrm{Pb}$, which may have been added in small amounts from equipment used for water purification. The concentrations of the trace elements in water samples from the wells and springs in Angono were more variable than those of the tap waters, and these were also below the WHO guideline values. The concentrations of $\mathrm{Cs}$ in all water samples were $<0.3 \mu \mathrm{g} / \mathrm{L}$. The trace-element concentrations of the waters from Angono River and Laguna Lake were almost the same as those of the well and spring waters.

Conclusion. At present, the concentrations of trace elements in daily life water consumed in Angono are at safe levels.

Key Words: Philippines, Angono, daily life water, trace element, health risk

\section{INTRODUCTION}

Corresponding author: Seiji Maruyama Kyoto Fission-Track Co., Ltd., 44-4 Oomiyaminamitajiri-cho, Kita-ku, Kyoto 603-8832, Japan

Email: ojigibito@icloud.com
Water is essential to sustain life and access to safe drinking water is important for the health and development of all human communities. ${ }^{1}$ There are three main risk factors to be considered for the provision of safe drinking water; chemical, radiological, and microbial hazards. Some elements [e.g., aluminum ( $\mathrm{Al})$, arsenic (As), cadmium $(\mathrm{Cd})$, mercury $(\mathrm{Hg})$ and lead $(\mathrm{Pb})]$, when present in drinking water, can cause biochemical toxicities to the human body. The radioactive nuclides of cesium (Cs), thorium (Th), and uranium (U) can also present radiological hazards. ${ }^{1,2}$

The provisional guideline concentration for As in drinking water, proposed by the World Health Organization 
(WHO), is $10 \mu \mathrm{g} / \mathrm{L} .{ }^{1}$ High concentrations of As in drinking water are linked to lung cancers and skin disorders ${ }^{2}$ and malnourished people and infants are particularly at risk. ${ }^{3}$ Cadmium accumulates in the kidneys, and can cause renal effects when consumed in drinking water. ${ }^{4}$ The WHO provisional guideline value for $\mathrm{Cd}$ is $3 \mu \mathrm{g} / \mathrm{L} .{ }^{1}$ A high intake of $\mathrm{Pb}$ can cause decreased IQ in children., The provisional guideline value for $\mathrm{Pb}$, proposed by $\mathrm{WHO}$ (2011), is $10 \mu \mathrm{g} / \mathrm{L}$. Uranium in drinking water can have negative effects on kidney function, ${ }^{7-9}$ and can also negatively influence fertility. ${ }^{10}$ The WHO provisional guideline value for $\mathrm{U}$ is $30 \mu \mathrm{g} / \mathrm{L}$, moreover, $\mathrm{U}$ is a naturally radioactive element, and the $\mathrm{WHO}$ guideline value for ${ }^{238} \mathrm{U}$ in drinking water is $10 \mathrm{~Bq} / \mathrm{L}$ (equivalent to $0.8 \mathrm{mg} / \mathrm{L}$ ). ${ }^{1}$

The health effects of chromium $(\mathrm{Cr})$ are dependent on its oxidation state. $\mathrm{Cr}$ (III) is an essential nutrient, used by the human body for sugar metabolism, ${ }^{11-13}$ whereas $\mathrm{Cr}$ (VI) is carcinogenic to humans by inhalation exposure. ${ }^{14}$ Given the difficulties in analyzing for $\mathrm{Cr}(\mathrm{VI})$ in isolation, the WHO proposed a provisional guideline value for total $\mathrm{Cr}$ in drinking water of $50 \mu \mathrm{g} / \mathrm{L} .{ }^{1}$

Thorium, like $\mathrm{U}$, is a naturally occurring radioactive element, and the guideline value for ${ }^{232} \mathrm{Th}$ in drinking water is $1 \mathrm{~Bq} / \mathrm{L}$, which is equivalent to $250 \mu \mathrm{g} / \mathrm{L} .{ }^{1}$ The biochemical toxicity of Th has not been observed to date, because concentrations of Th in drinking water and foods are typically too low to have a discernible effect. For example, in bottled mineral waters distributed in Japan, Th concentrations are typically $<3 \mathrm{ng} / \mathrm{L} .{ }^{15}$

The two short-lived radioisotopes of $\mathrm{Cs}\left({ }^{134} \mathrm{Cs}\right.$ and ${ }^{137} \mathrm{Cs}$ ) are considered to be the predominant radionuclides found in water, which are mainly derived from activities associated with the nuclear industry, including nuclear power plants and weapons. ${ }^{1} \mathrm{WHO}$ advised that the guideline value of radioactive Cs in drinking water should be $<10 \mathrm{~Bq} / \mathrm{L}$. ${ }^{1}$ Conversely, nonradioactive ${ }^{133} \mathrm{Cs}$ is widely distributed in Earth's crust (1.5 ppm in the continental crust). ${ }^{16}$ Cesium is chemically similar to the essential element of potassium $(\mathrm{K}) .{ }^{17}$ The concentrations of $\mathrm{Cs}$ in European bottled waters vary up to a maximum value of $415 \mu \mathrm{g} / \mathrm{L}$, and $\mathrm{Cs}_{\mathrm{s}}$ is considered to be a characteristic component of "mineral water". ${ }^{18}$ At present, a guideline value for $\mathrm{Cs}$ in drinking water, in terms of its biochemical toxicity, has not been proposed by WHO. ${ }^{1}$ However, acute or chronic toxicity resulting from high concentrations of $\mathrm{Cs}$ has been observed. ${ }^{19-21}$ For example, high $\mathrm{Cs}$ intake may negatively influence clastogenic activity. ${ }^{22}$ To fully evaluate the possible health risks caused by the chemical toxicity of the elements $\mathrm{Cs}$ and Th in drinking water, analytical data on the concentrations of these elements in drinking water must be determined.

An evaluation of the health risks that result from the consumption of drinking water is increasingly important at a national, regional, and local level in all countries, especially those countries currently working to improve access to safe drinking water. A recent study by Saito and Nakano, ${ }^{23}$ obtained water samples from rivers, springs, lakes, wells, and tap water in the areas surrounding Laguna Lake on Luzon Island, in the Philippines, during the dry season (March and May) of 2011, analyzed the chemical composition of their water samples using solution nebulization inductively coupled plasma mass spectrometry (SN-ICP-MS). They concluded that the concentrations of the trace elements $\mathrm{Cr}, \mathrm{Cd}$, and $\mathrm{Pb}$ are relatively high (typically $0.1-2.0 \mu \mathrm{g} / \mathrm{L}$ $\mathrm{Pb}$ ) in all types of water sample that they obtained from the region on the western lakeshore (i.e., Metropolitan Manila, abbreviated to Metro Manila) in comparison with those obtained from the eastern region (typically $<0.3 \mu \mathrm{g} / \mathrm{L}$ $\mathrm{Pb}){ }^{23}$ Moreover, Kada ${ }^{24}$ referred to the analytical results of Saito and $\mathrm{Nakano}^{23}$ and argued that the $\mathrm{Pb}$ pollution of Laguna Lake is currently causing harmful effects on the brain development of children living around the lake. If extraordinary high concentrations of trace elements are obtained, the cause of them should be carefully investigated in order to prevent and eliminate the potential health risks, and the associated social inequality based on accessibility to safe drinking water and food in the Philippines.

In this paper, we present the concentrations of seven trace elements $(\mathrm{Cr}, \mathrm{As}, \mathrm{Cd}, \mathrm{Cs}, \mathrm{Pb}$, Th, and $\mathrm{U})$ in daily life water (including tap, well, and spring waters) consumed in the town of Angono, Rizal in the Philippines, in order to evaluate any health risks from these trace elements. Angono has a population of $>110,000$ as of $2015,{ }^{25}$ and it is located $\sim 20 \mathrm{~km}$ east of Manila. Angono is not within Metro Manila, but for practical purposes, it can be regarded as a part of Metro Manila's conurbation. The Manila Water Company Inc. currently supplies tap water to Angono, and well and spring waters are also used as a freshwater source, mainly for washing and bathing. Angono provides a suitable example of an urban region in the Philippines, with an appropriate population scale, for the evaluation of the health risks posed by trace elements in daily life water.

\section{METHODS}

\section{Samples}

Samples of daily life water, including six tap, ten wells, and two spring waters were obtained in Angono between October 9 and 12, 2015 (the wet season). Water samples were also obtained from the Angono River and Laguna Lake, as natural water sources with a close relationship to daily life in Angono. Six purified tap waters, which are sold in refilled PET bottles by water refilling stations in Angono, were also obtained for comparison with the normal (i.e., "unpurified") tap water. In these refilling stations, ion-exchange resin, activated carbon filtration, and UV light sterilization is used to purify tap water. The sampling locations are shown in Figure 1 . The sampling locations were selected based on information provided by barangay offices of Angono. In Mahabang Parang, which is a barangay in a mountainous area, the well and spring waters are commonly used as daily life water compared with 


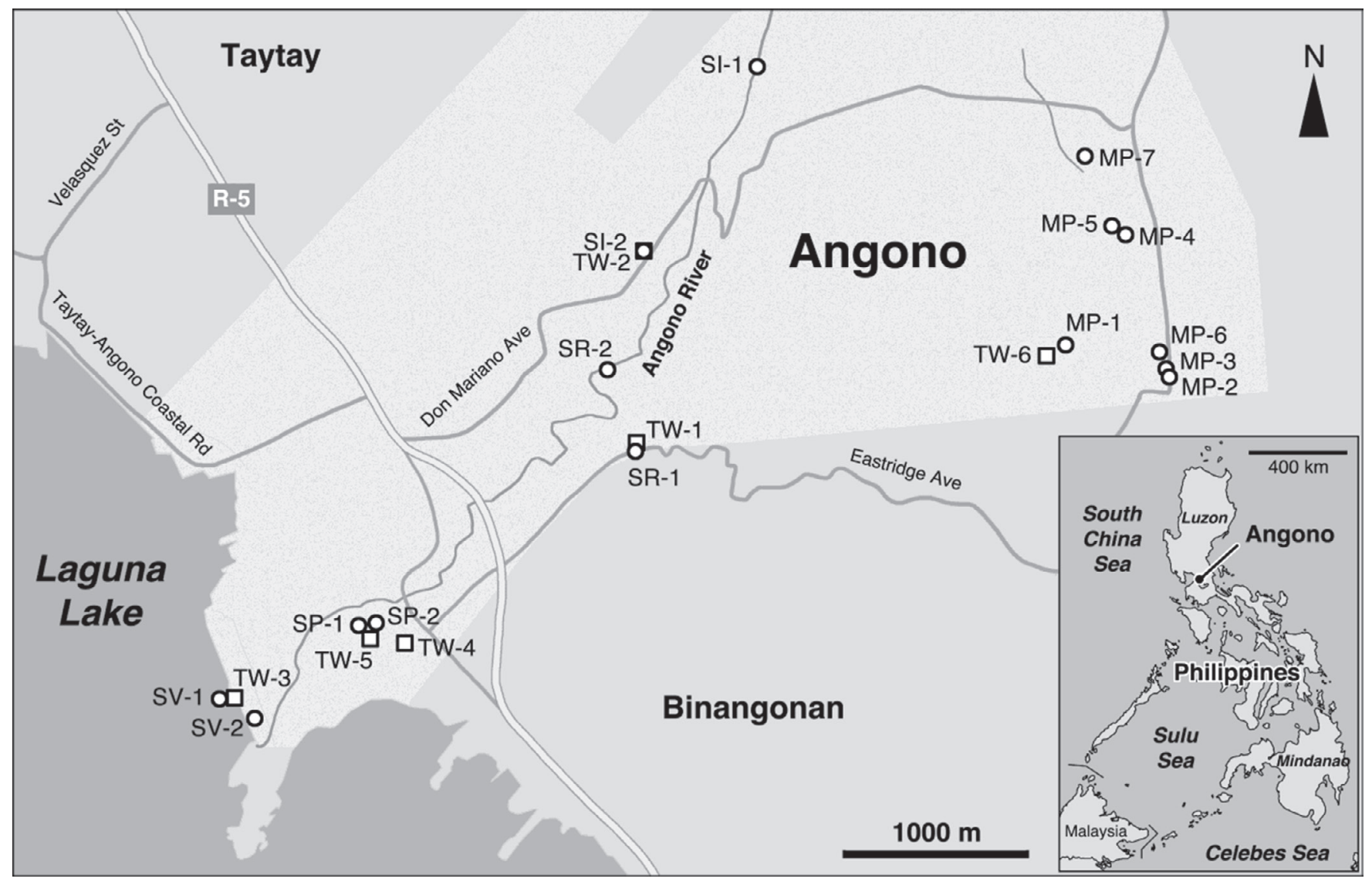

Figure 1. Map showing the water sampling locations in Angono. Circles represent the sampling locations for well/spring, river, and lake water samples. Squares represent the sampling locations for tap water samples. The prefix "AN-" is omitted from the sample names in this figure. The sampling locations of the purified tap water refilling stations are not shown in this figure, in order to protect the identity of the purified tap water products they supply. It is important to note that all these purified tap waters can be considered as completely safe drinking water. A map showing the location of Angono in the Philippines is also embedded in this figure.

tap water. Therefore, we obtained a larger number of the well and spring water samples in Mahabang Parang. Additional details about the sampling are described by Kato et al. ${ }^{26}$

The water samples were filtered using $0.22-\mu \mathrm{m}$ membrane filters that were attached to the sampling syringes and used to place the water into $100 \mathrm{~mL}$ polyethylene bottles (Figure 2). The bottles were filled to the top with each water sample in order to avoid aeration. During the sampling period, purified tap waters were obtained in Angono. The purified tap waters were not filtered. All of the water samples were kept at a few degrees Celsius in a cold box and placed in a refrigerator immediately after sampling until preparation for instrumental analyses in Japan were ready.

\section{Analytical procedures}

The quantitative analyses of seven elements $(\mathrm{Cr}, \mathrm{As}$, $\mathrm{Cd}, \mathrm{Cs}, \mathrm{Pb}$, Th, and $\mathrm{U}$ ) in the water samples were carried out using a Thermo Fisher Scientific iCAP Qc ICP-MS at Kyoto University between October 18 and 23, 2015. A Glass Expansion MicroMist 100 nebulizer (concentric type, 0.1
$\mathrm{mL} / \mathrm{min}$ ) was used at a flow rate of $1.0-1.1 \mathrm{~L} / \mathrm{min}$ with $\mathrm{Ar}$ as a nebulizer gas. The flow rates of the cool (Ar) and auxiliary gas (Ar) were set to 14 and $0.8 \mathrm{~L} / \mathrm{min}$, respectively. The RF power was $1550 \mathrm{~W}$. Kinetic energy discrimination (KED) was used as the operational mode of the ICP-MS, in order to obtain higher sensitivities for the measurements of the signal intensities of the heavier elements. The flow rate of the collision cell gas $\left(\mathrm{He}+\mathrm{H}_{2}\right)$ was $4.5-5.5 \mathrm{~mL} / \mathrm{min}$. Each water sample had $2 \%$ (v/v) of nitric acid (Kanto Chemical Co., Inc.; Semiconductor grade) and $0.25 \mu \mathrm{g} / \mathrm{L}$ of standard solutions of In and $\mathrm{Bi}(1000 \mathrm{mg} / \mathrm{L}$; Kanto Chemical Co., Inc.) added to them. The analyzed mass numbers were ${ }^{52} \mathrm{Cr},{ }^{75} \mathrm{As},{ }^{111} \mathrm{Cd}$, ${ }^{115} \mathrm{In},{ }^{133} \mathrm{Cs},{ }^{208} \mathrm{~Pb},{ }^{209} \mathrm{Bi},{ }^{232} \mathrm{Th}$, and ${ }^{238} \mathrm{U}$. A multi-element standard solution (Tama Chemicals "Solution for data quality control, Discussion Group for Plasma Spectrochemistry"; $100 \mu \mathrm{g} / \mathrm{L}$ of 20 elements including $\mathrm{Cr}, \mathrm{As}, \mathrm{Cd}, \mathrm{Pb}$, Th, and U) and a Cs standard solution (1000 mg/L Cs; Kanto Chemical Co., Inc.) were used for calibration of the instrument. A SPEX Custom Assurance Standard XSTC-1252-100 standard solution (10 mg/L of 12 elements) was also used. 

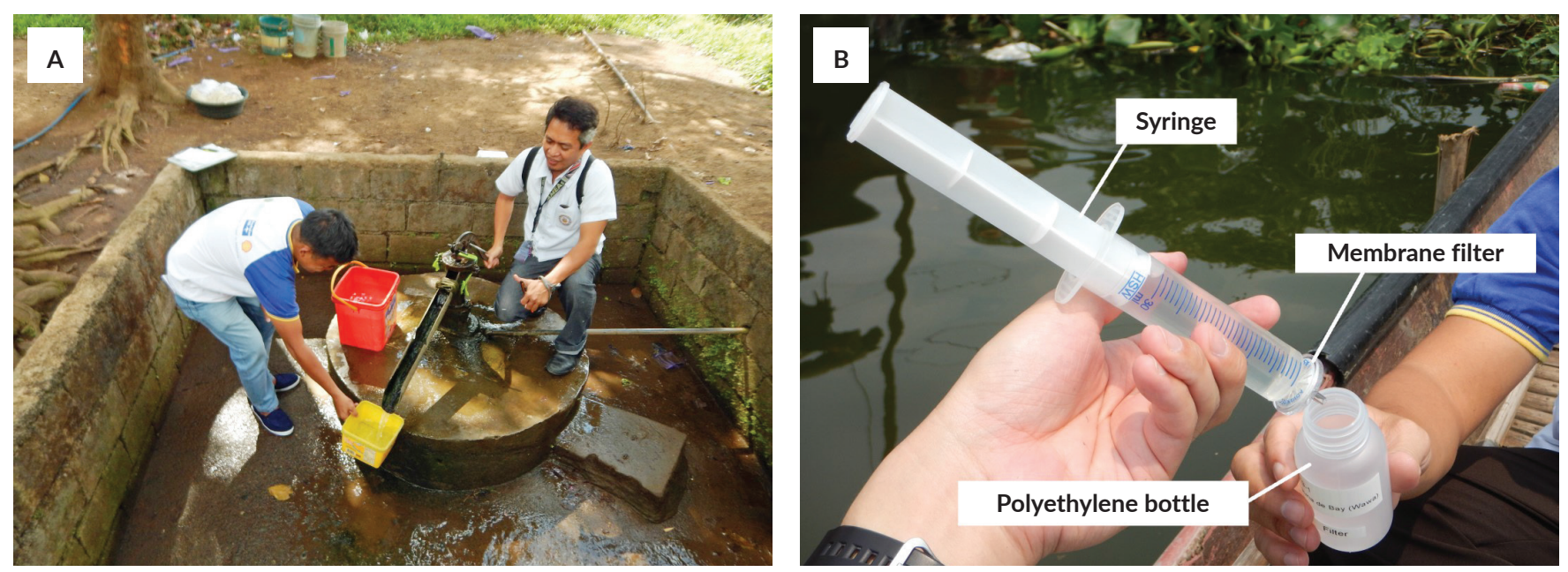

Figure 2. Photos of $(A)$ sampling of spring water pumped by a piston pump in Mahabang Parang (AN-MP-1) and (B) a set of water sampling tools. Each water sample in the syringe was poured into the polyethylene bottle through the membrane filter. The photos (A) and (B) were taken on October 10 and 9, 2015, respectively.

At the start of each session, a Milli-Q water solution of $2 \%(\mathrm{v} / \mathrm{v})$ nitric acid and two internal standards were analyzed in order to determine the blank signals of the individual elements. The standard solutions were then analyzed in order of concentration, followed by the water samples. Each water sample was analyzed five times, and the final concentration of each trace element, in each sample, was obtained as the mean of the five analytical values. The washout duration for each sample was set to 30 seconds. The analytical data were processed using Thermo Fisher Scientific Qtegra Intelligent Scientific Data Solution software.

The Milli-Q water used in this study was produced by Merck Millipore Milli-Q Element A10 and Elix Advantage 3 Water Purification Systems. Sample preparation was carried out in a class 1000 cleanroom. During the analyses, in order to minimize the incorporation of dust particles from the atmosphere, the bottle of each water sample was covered with its cap, and the measurement duration of each sample limited to $<8$ minutes.

The concentrations of total dissolved solids (TDS) represent the total amount of mobile charged ions in a solution. The TDS of the unpurified tap water and the natural surface water samples (i.e., the well, spring, river, and lake waters) were measured during sampling in the field using a HM TDS-3 handheld water quality tester (manufactured by HM Digital Inc.). The TDS values of the packaged products (i.e., the purified tap waters produced at the refilling stations) were not measured.

\section{RESULTS AND DISCUSSION}

\section{Tap waters}

The concentrations of the seven trace elements in six unpurified Angono tap water samples are summarized in Table 1. The RSD values of the mean concentrations of all the elements except Th are less than 10\%. The concentrations of $\mathrm{Cr}, \mathrm{As}, \mathrm{Cd}, \mathrm{Pb}$, and $\mathrm{U}$ are below the provisional guideline values proposed by $\mathrm{WHO},{ }^{1}$ and those of Th are also $<0.5 \%$ of the guideline value for the natural radionuclide ${ }^{232} \mathrm{Th}$ in WHO. ${ }^{1}$ The concentrations of $\mathrm{As}, \mathrm{Cd}$, and $\mathrm{Pb}$ are also below the Philippine National Standards for DrinkingWater (PNSDW) updated in 2016, ${ }^{27}$ which are the same as the provisional WHO guideline values. The concentrations of $\mathrm{Pb}$ in the unpurified tap water samples range widely (9-124 ng/L), and those of $\mathrm{Cd}$ are $<12 \mathrm{ng} / \mathrm{L}$ (Table 1). A small quantity of $\mathrm{Pb}$ may be incorporated into the tap water from fittings and pipes containing $\mathrm{Pb}$ during its distribution in Angono. Sample AN-TW-4 has the lowest concentration of $\mathrm{Pb}(9 \mathrm{ng} / \mathrm{L}$; Table 1$)$ and, therefore, it may represent the original level of $\mathrm{Pb}$ in Angono tap water. The pipes of the Angono tap water network are made of iron, and a vinyl hose is used to distribute water from the terminal to each house. Therefore, contamination of tap water by $\mathrm{Pb}$ from pipes is minimized. The low RSD values of TDS and $\mathrm{Cr}, \mathrm{As}, \mathrm{Cs}$, and $\mathrm{U}(2 \%-10 \%$; Table 1$)$ suggest that the Angono tap waters can be regarded as nearly homogeneous.

The concentrations of the seven trace elements in six purified tap waters produced at the refilling stations in Angono are summarized in Table 2. The concentrations of $\mathrm{Cr}$ in the purified tap waters are $<166 \mathrm{ng} / \mathrm{L}$, which is $>25 \%$ lower than the unpurified tap waters (Tables 1 and 2). Concentrations of As in the purified tap waters are $16-231 \mathrm{ng} / \mathrm{L}$, corresponding to $6 \%-85 \%$ of those of the unpurified tap water values. Moreover, concentrations of $\mathrm{Cd}$ in the purified tap waters are $<10 \%$ of those of the unpurified tap waters (Tables 1 and 2). With the exception of sample AN-PTW-2 concentrations of $U$ in the purified tap waters are $<20 \%$ of those of the unpurified tap waters, and concentrations of Th in the purified tap waters are below the detection limits (Table 2). 
Table 1. Concentrations of seven trace elements and TDS values in tap water samples in Angono

\begin{tabular}{|c|c|c|c|c|c|c|c|c|c|c|c|c|c|c|c|c|}
\hline \multirow[b]{2}{*}{$\begin{array}{c}\text { Sample } \\
\text { No. }\end{array}$} & \multirow[b]{2}{*}{ Barangay } & \multicolumn{2}{|c|}{$\mathrm{Cr}$} & \multicolumn{2}{|c|}{ As } & \multicolumn{2}{|c|}{$\mathrm{Cd}$} & \multicolumn{2}{|c|}{ Cs } & \multicolumn{2}{|c|}{$\mathrm{Pb}$} & \multicolumn{2}{|c|}{ Th } & \multicolumn{2}{|c|}{ U } & \multirow{2}{*}{$\begin{array}{c}\text { TDS } \\
\text { (mg/L) }\end{array}$} \\
\hline & & (ng/L) & $\begin{array}{l}\text { RSD } \\
(\%)\end{array}$ & (ng/L) & $\begin{array}{l}\text { RSD } \\
(\%)\end{array}$ & (ng/L) & $\begin{array}{l}\text { RSD } \\
(\%)\end{array}$ & (ng/L) & $\begin{array}{l}\text { RSD } \\
(\%)\end{array}$ & (ng/L) & $\begin{array}{l}\text { RSD } \\
(\%)\end{array}$ & (ng/L) & $\begin{array}{l}\text { RSD } \\
(\%)\end{array}$ & (ng/L) & $\begin{array}{l}\text { RSD } \\
(\%)\end{array}$ & \\
\hline AN-TW-1 & San Roque & 222.7 & 1.3 & 268.4 & 2.1 & 12.3 & 3.3 & 4.1 & 2.2 & 123.6 & 1.1 & 1.4 & 25.8 & 13.0 & 1.1 & 66 \\
\hline AN-TW-2 & San Ishidro & 222.0 & 1.0 & 270.0 & 2.0 & 1.9 & 8.8 & 4.0 & 1.9 & 48.8 & 0.9 & 0.5 & 15.2 & 12.7 & 1.4 & 69 \\
\hline AN-TW-3 & San Vicente & 213.3 & 0.7 & 261.4 & 1.5 & 8.4 & 3.9 & 4.9 & 2.5 & 71.2 & 1.2 & BLOQ & & 12.1 & 1.4 & 59 \\
\hline AN-TW-4 & San Pedro & 221.7 & 1.0 & 276.4 & 0.8 & 1.6 & 8.3 & 3.9 & 2.9 & 9.0 & 1.1 & BLOQ & & 12.7 & 0.7 & 70 \\
\hline AN-TW-5 & San Pedro & 223.6 & 1.1 & 277.0 & 2.0 & 0.7 & 6.6 & 3.6 & 1.6 & 53.6 & 1.1 & BLOQ & & 12.5 & 1.2 & 67 \\
\hline AN-TW-6 & Mahabang Parang & 220.7 & 0.7 & 273.2 & 0.9 & 0.6 & 7.1 & 4.1 & 2.3 & 108.7 & 0.6 & BLOQ & & 13.2 & 0.5 & 65 \\
\hline Mean & & 220.7 & 1.7 & 271.1 & 2.2 & 4.3 & 115.1 & 4.1 & 10.2 & 69.2 & 60.7 & 0.9 & 70.6 & 12.7 & 3.1 & 66 \\
\hline Limit of qu & uantification (LOQ) & 5.0 & & 9.4 & & 0.3 & & 0.2 & & 0.4 & & 0.4 & & $<0.1$ & & \\
\hline
\end{tabular}

Notes: The mean value of the concentrations of Th are calculated from the values of AN-TW-1 and -2. The relative standard deviation (RSD) value of TDS is 5.9\%. BLOQ: Below LOQ.

Table 2. Concentrations of seven trace elements in water samples obtained in water refilling stations in Angono

\begin{tabular}{|c|c|c|c|c|c|c|c|c|c|c|c|c|c|c|}
\hline \multirow[b]{2}{*}{ Sample name } & \multicolumn{2}{|c|}{$\mathrm{Cr}$} & \multicolumn{2}{|c|}{ As } & \multicolumn{2}{|c|}{$\mathrm{Cd}$} & \multicolumn{2}{|c|}{ Cs } & \multicolumn{2}{|c|}{$\mathrm{Pb}$} & \multicolumn{2}{|c|}{ Th } & \multicolumn{2}{|c|}{$\mathbf{U}$} \\
\hline & (ng/L) & $\begin{array}{l}\text { RSD } \\
(\%)\end{array}$ & (ng/L) & $\begin{array}{l}\text { RSD } \\
(\%)\end{array}$ & (ng/L) & $\begin{array}{l}\text { RSD } \\
(\%)\end{array}$ & (ng/L) & $\begin{array}{l}\text { RSD } \\
(\%)\end{array}$ & (ng/L) & $\begin{array}{l}\text { RSD } \\
(\%)\end{array}$ & (ng/L) & $\begin{array}{l}\text { RSD } \\
(\%)\end{array}$ & (ng/L) & $\begin{array}{l}\text { RSD } \\
(\%)\end{array}$ \\
\hline AN-PTW-1 & 17.3 & 3.2 & 15.9 & 5.9 & BLOQ & & 144.5 & 0.9 & 17.2 & 1.1 & BLOQ & & 0.5 & 3.6 \\
\hline AN-PTW-2 & 22.1 & 3.9 & 24.6 & 4.5 & 0.8 & 16.4 & 0.7 & 7.3 & 234.0 & 0.4 & BLOQ & & BLOQ & \\
\hline AN-PTW-3 & 86.8 & 1.3 & 153.2 & 3.6 & 0.5 & 12.8 & 1.1 & 5.6 & 158.6 & 0.5 & BLOQ & & 2.5 & 1.1 \\
\hline AN-PTW-4 & 165.9 & 1.4 & 230.5 & 2.4 & 1.2 & 6.3 & 3.6 & 4.7 & 169.8 & 0.5 & BLOQ & & 12.5 & 0.4 \\
\hline AN-PTW-5 & BLOQ & & 42.1 & 2.6 & 0.8 & 5.1 & 12.2 & 2.1 & 254.8 & 0.7 & BLOQ & & 0.5 & 3.4 \\
\hline AN-PTW-6 & 41.5 & 44.0 & 35.2 & 4.6 & 1.2 & 6.4 & 1.0 & 3.3 & 1057.7 & 0.5 & BLOQ & & 0.3 & 5.4 \\
\hline \multicolumn{15}{|c|}{ Limit of quantification (LOQ) } \\
\hline AN-PTW-1 & 8.7 & & 9.2 & & 0.4 & & 0.3 & & 0.3 & & 0.1 & & 0.1 & \\
\hline AN-PTW-2-6 & 15.4 & & 13.4 & & 0.4 & & 0.4 & & 0.6 & & 0.2 & & $<0.1$ & \\
\hline
\end{tabular}

RSD: Relative Standard Deviation. BLOQ: Below LOQ.

However, the concentrations of $\mathrm{Pb}$ in the purified tap waters $(17-1058 \mathrm{ng} / \mathrm{L}$; Table 2$)$ are up to nine times higher than those of the unpurified tap waters $(9-124 \mathrm{ng} / \mathrm{L}$; Table 1). This evidence suggests that the equipment used for water purification probably adds $\mathrm{Pb}$ to the tap water. The equipment used at the refilling stations can reduce abundances of most of the elements in the tap water, although it may simultaneously add small quantities of some elements, including $\mathrm{Pb}$.

The concentrations of $\mathrm{Pb}$ in the unpurified and purified tap water samples obtained in this study are $0.1 \%-1.2 \%$ and $0.2 \%-10.6 \%$, respectively, of the WHO guideline value for $\mathrm{Pb}$ in drinking water $(10 \mu \mathrm{g} / \mathrm{L}) .^{1}$ The analytical results of this study suggest that both the unpurified and purified tap waters available in Angono do not contain $\mathrm{Pb}$ at significantly hazardous levels as set by WHO. ${ }^{1}$ The unpurified tap water distributed to Angono may be more suitable than the purified tap water for reducing $\mathrm{Pb}$ intake. Rosborg et al. ${ }^{2}$ suggested that $\mathrm{Pb}$ in tap water can generally be reduced by flushing water pipes for a short time prior to usage. Considering the concentrations of trace elements in the tap water sampled in Angono are low, it could be a simple and inexpensive way to reduce any potential health risks associated with $\mathrm{Pb}$ intake from the tap water.

\section{Well and spring waters}

The concentrations of the seven trace elements in ten well and two spring water samples that are used for household purposes in Angono are summarized in Table 3. The TDS values of the well and spring waters range more widely $(60-560 \mathrm{mg} / \mathrm{L}$; Table 3$)$ than those of the unpurified tap water $(60-70 \mathrm{mg} / \mathrm{L}$; Table 1). The concentrations of $\mathrm{Cr}, \mathrm{As}, \mathrm{Cd}, \mathrm{Pb}$, and $\mathrm{U}$ in all well water samples are below the provisional guideline values proposed by WHO. ${ }^{1}$ Those of Th in all well water samples are $<2 \mathrm{ng} / \mathrm{L}$, with the exception of sample AN-MP-1 (12 $\mathrm{ng} / \mathrm{L}$; Table 3). Concentrations of $\mathrm{Cs}$ in the well waters from Mahabang Parang and San Pedro (28-160 ng/L) are higher than those from the other barangays (4-7 ng/L). This difference may be due to the geological and/or geochemical properties of the well water sources.

The concentrations of $\mathrm{Cr}$ in the well waters $(<103$ $\mathrm{ng} / \mathrm{L}$; Table 3) are $<47 \%$ of those in the tap waters $(\sim 221 \mathrm{ng} / \mathrm{L}$; Table 1) with the exception of sample ANMP-6 $(\sim 2.7 \mu \mathrm{g} / \mathrm{L})$. These values are closer to those of the purified tap waters $(<166 \mathrm{ng} / \mathrm{L}$; Table 2$)$. Concentrations of As in the well water samples (23-692 ng/L) are slightly higher than both the unpurified and purified tap waters (Tables 1 and 2, respectively). The concentrations of $\mathrm{Cd}$ 
Trace Elements in Daily Life Water Consumed in Angono

Table 3. Concentrations of seven trace elements in water samples obtained from wells, rivers, and lake in Angono

\begin{tabular}{|c|c|c|c|c|c|c|c|c|c|c|c|c|c|c|c|c|}
\hline \multirow{2}{*}{$\begin{array}{c}\text { Barangay } \\
\text { and } \\
\text { Sample No. }\end{array}$} & \multirow[b]{2}{*}{ Classification } & \multicolumn{2}{|c|}{$\mathrm{Cr}$} & \multicolumn{2}{|c|}{ As } & \multicolumn{2}{|c|}{$\mathrm{Cd}$} & \multicolumn{2}{|c|}{ Cs } & \multicolumn{2}{|c|}{$\mathrm{Pb}$} & \multicolumn{2}{|c|}{ Th } & \multicolumn{2}{|c|}{ U } & \multirow{2}{*}{$\begin{array}{c}\text { TDS } \\
\text { (mg/L) }\end{array}$} \\
\hline & & (ng/L) & $\begin{array}{l}\text { RSD } \\
(\%)\end{array}$ & (ng/L) & $\begin{array}{c}\text { RSD } \\
\text { (\%) }\end{array}$ & (ng/L) & $\begin{array}{l}\text { RSD } \\
(\%)\end{array}$ & (ng/L) & $\begin{array}{c}\text { RSD } \\
\text { (\%) }\end{array}$ & (ng/L) & $\begin{array}{l}\text { RSD } \\
(\%)\end{array}$ & (ng/L) & $\begin{array}{l}\text { RSD } \\
(\%)\end{array}$ & (ng/L) & $\begin{array}{c}\text { RSD } \\
\text { (\%) }\end{array}$ & \\
\hline \multicolumn{17}{|l|}{ San Roque } \\
\hline AN-SR-1 & Well & BLOQ & & 22.5 & 5.7 & 3.8 & 5.2 & 4.3 & 2.4 & 7.0 & 1.7 & 2.2 & 29.7 & 29.0 & 1.4 & 222 \\
\hline AN-SR-2 & Angono River & 151.0 & 1.2 & 279.4 & 1.2 & 3.1 & 4.6 & 6.9 & 1.7 & 56.8 & 1.8 & 1.1 & 13.9 & 63.0 & 0.7 & 145 \\
\hline \multicolumn{17}{|l|}{ San Ishidro } \\
\hline AN-SI-1 & Angono River & 39.6 & 1.9 & 310.7 & 1.4 & 2.0 & 4.3 & 31.1 & 1.1 & 10.2 & 0.4 & 1.8 & 3.5 & 42.0 & 0.7 & 113 \\
\hline AN-SI-2 & Well & 55.0 & 1.2 & 179.9 & 2.1 & 15.8 & 0.7 & 3.3 & 1.1 & 8.2 & 1.8 & BLOQ & & 143.7 & 1.4 & 320 \\
\hline \multicolumn{17}{|l|}{ San Vicente } \\
\hline AN-SV-1 & Laguna Lake & 96.5 & 1.4 & 759.8 & 1.1 & 0.6 & 10.4 & 9.5 & 2.4 & 6.0 & 0.7 & BLOQ & & 24.7 & 0.4 & 144 \\
\hline AN-SV-2 & Well & 37.4 & 4.0 & 928.0 & 1.8 & 30.7 & 2.7 & 4.0 & 3.7 & 2.3 & 1.7 & BLOQ & & 1840.4 & 2.8 & 564 \\
\hline \multicolumn{17}{|c|}{ Mahabang Parang } \\
\hline AN-MP-1 & pump/spring & 46.7 & 2.3 & 498.3 & 1.5 & 8.6 & 1.9 & 141.3 & 1.6 & 15.4 & 3.2 & 12.4 & 8.0 & 129.1 & 1.0 & 60 \\
\hline AN-MP-2 & Well & 102.7 & 1.3 & 691.8 & 2.1 & 2.0 & 5.8 & 101.3 & 0.6 & 1.2 & 18.9 & 1.3 & 17.6 & 18.3 & 0.5 & 87 \\
\hline AN-MP-3 & Well & 74.5 & 1.8 & 582.3 & 1.0 & 7.7 & 2.9 & 144.9 & 0.8 & 38.0 & 41.7 & BLOQ & & 64.8 & 1.1 & 130 \\
\hline AN-MP-4 & Well & 15.8 & 3.3 & 113.4 & 1.1 & 4.1 & 4.8 & 159.9 & 1.2 & 14.7 & 75.4 & BLOQ & & 46.0 & 1.3 & 175 \\
\hline AN-MP-5 & Spring & 32.0 & 4.8 & 169.7 & 1.5 & 20.2 & 2.5 & 277.7 & 0.9 & 10.4 & 1.7 & BLOQ & & 38.3 & 1.0 & 251 \\
\hline AN-MP-6 & Deep well & 2714.4 & 1.8 & 644.2 & 1.8 & 3.8 & 3.7 & 37.0 & 2.0 & 41.8 & 0.5 & BLOQ & & 27.3 & 0.4 & 100 \\
\hline AN-MP-7 & Well & 49.6 & 0.7 & 381.4 & 0.6 & 16.7 & 2.0 & 28.2 & 0.6 & 4.4 & 4.5 & BLOQ & & 91.5 & 0.5 & 175 \\
\hline \multicolumn{17}{|l|}{ San Pedro } \\
\hline AN-SP-1 & Deep well & 10.0 & 10.6 & 418.9 & 0.8 & 56.3 & 1.0 & 185.7 & 1.8 & 94.5 & 1.0 & BLOQ & & 1203.1 & 0.6 & 498 \\
\hline AN-SP-2 & Well & 6.7 & 4.2 & 424.9 & 1.7 & 56.4 & 0.7 & 171.3 & 0.4 & 151.0 & 0.3 & BLOQ & & 1167.4 & 1.0 & 494 \\
\hline \multicolumn{17}{|c|}{ Limit of quantification (LOQ) } \\
\hline \multicolumn{2}{|c|}{ AN-SR-1-AN-SV-2 } & \multicolumn{2}{|l|}{15.5} & \multicolumn{2}{|l|}{6.4} & \multicolumn{2}{|l|}{0.4} & \multicolumn{2}{|l|}{0.4} & \multicolumn{2}{|l|}{0.4} & 0.3 & & \multicolumn{2}{|l|}{$<0.1$} & \\
\hline \multirow{2}{*}{\multicolumn{2}{|c|}{ AN-MP-1-7 }} & \multicolumn{2}{|l|}{7.6} & \multicolumn{2}{|l|}{8.5} & \multicolumn{2}{|l|}{0.5} & \multicolumn{2}{|l|}{0.2} & 0.7 & & 1.0 & & $<0.1$ & & \\
\hline & & 5.0 & & 9.4 & & 0.3 & & 0.2 & & 0.4 & & 0.4 & & 0.1 & & \\
\hline
\end{tabular}

RSD: Relative Standard Deviation. BLOQ: Below LOQ.

in the well water samples range more widely $(2-56 \mathrm{ng} / \mathrm{L}$; Table 3) than those in the unpurified tap waters $(1-12 \mathrm{ng} / \mathrm{L}$; Table 1). The range of the $\mathrm{Pb}$ concentrations of the well waters $(1-151 \mathrm{ng} / \mathrm{L}$; Table 3$)$ is comparable to that of the tap waters (9-124 ng/L; Table 1), and the concentrations of $\mathrm{Pb}$ in most well water samples are lower than those of the purified tap waters (17-1058 ng/L; Table 2).

The concentrations of $U$ in the well waters are 1.4-142 times (18-1840 ng/L; Table 3) those of the unpurified tap waters ( $13 \mathrm{ng} / \mathrm{L}$; Table 1). Concentrations of $\mathrm{U}$ in the well waters from San Vicente and San Pedro are $>1 \mu \mathrm{g} / \mathrm{L}$, whereas those from Mahabang Parang are lower (18-92 ng/L; Table 3). Concentrations of Th in the well water samples ( $<2 \mathrm{ng} / \mathrm{L}$; Table 3$)$ are comparable to those of the unpurified tap waters. The concentrations of $\mathrm{Cs}$ in the well water samples from Mahabang Parang and San Pedro range from $28-278 \mathrm{ng} / \mathrm{L}$, whereas those from the other barangays are lower (3-4 ng/L; Table 3) and almost identical to unpurified tap waters. The concentrations of the seven trace elements in the spring water samples (ANMP-1 and -5) are comparable to those of the well waters from Mahabang Parang (Table 3).

\section{Angono River and Laguna Lake}

The concentrations of the seven trace elements in Angono River (AN-SR-2 and AN-SI-1) and Laguna Lake (AN-SV-1) of the wet season are sufficiently below the provisional guideline values proposed by $\mathrm{WHO}^{1}$ (Table 3). The TDS values for the Angono River samples are 110-150 $\mathrm{mg} / \mathrm{L}$, and the value for the Laguna Lake sample is similar to those of the river $(\sim 140 \mathrm{mg} / \mathrm{L}$; Table 3$)$.

The concentrations of $\mathrm{Cr}, \mathrm{As}, \mathrm{Cd}$, and $\mathrm{Pb}$ in the Angono River determined by Saito and $\mathrm{Nakano}^{23}$ are $0.2-0.5,<1.5$, $0.005-0.010$, and $0.1-0.3 \mu \mathrm{g} / \mathrm{L}$, respectively. These are approximately $130 \%-330 \%,<540 \%, 160 \%-330 \%$, and 180-530\%, respectively, of those of Angono River sample AN-SR-2 (Table 3). Moreover, the concentrations listed above are approximate 500\%-1260\%, <480\%, 250\%-500\%, and 980\%-2940\%, respectively, of those of Angono River sample AN-SI-1 (Table 3). The concentrations of $\mathrm{Cr}, \mathrm{As}, \mathrm{Cd}$, and $\mathrm{Pb}$ determined by Saito and $\mathrm{Nakano}^{23}$ in their sample taken from Laguna Lake at the location nearest to Angono are $<0.2,1.5-5.0,0.005-0.010$, and $<0.1 \mu \mathrm{g} / \mathrm{L}$, respectively. These values are $<210 \%, 200 \%-660 \%, 830 \%-1670 \%$, and $<1670 \%$, respectively, of those of the Laguna Lake sample in this study (AN-SV-1; Table 3). 
Trace Elements in Daily Life Water Consumed in Angono

If the waters of the Angono River and Laguna Lake do contain $\mathrm{Pb}$ at the analytical values determined by Saito and Nakano, ${ }^{23}$ it is important to note that in their river and lake samples closest to Angono obtained in the dry season the concentrations of $\mathrm{Pb}$ are still considerably lower than those considered to be hazardous $(<3 \%$ of the WHO guideline value). ${ }^{1}$

\section{CONCLUSIONS}

In order to evaluate the health risks posed by trace elements in daily life water, the concentrations of seven trace elements $(\mathrm{Cr}, \mathrm{As}, \mathrm{Cd}, \mathrm{Cs}, \mathrm{Pb}, \mathrm{Th}$, and $\mathrm{U})$ in unpurified-purified tap, well, and spring waters available in Angono, Rizal in the Philippines have been analyzed. The concentrations of the well-known toxic elements (i.e., Cr, $\mathrm{As}, \mathrm{Cd}, \mathrm{Pb}$, and $\mathrm{U}$ ) and radioactive $\mathrm{Th}$ in all water samples are substantially below the guideline values proposed by WHO. ${ }^{1}$ Waters from Angono River and Laguna Lake have concentrations almost comparable with those of the well and spring water samples obtained in Angono. Our analytical results suggest that health risks from the trace elements in the daily life waters and river-lake waters are generally low. The values of Hazard Quotient (HQ), which is the proportion of the exposure concentration to the reference concentration [e.g., ${ }^{28}$, of the trace elements (except for Cs) in the studied water samples are $<0.1$. The concentrations of $\mathrm{Cs}$ in the water samples obtained in Angono are $<0.3 \mu \mathrm{g} / \mathrm{L}$. The data for $\mathrm{Cs}$ in the daily life water samples obtained in this study will be helpful for future evaluations of health risks from various daily life water sources in the Philippines.

Carefully planned sampling and detailed evaluation of the quality of daily life water is required in other areas alongside Laguna Lake, such as Calamba and Los Baños. Moreover, the trace-element data of this and other studies should be carefully and repeatedly checked, in order to better understand and ultimately reduce the associated health risks and resultant social inequality associated with contaminated drinking waters.

In addition to the trace elements investigated here, the contamination and pollution of daily life water by organic matter, including microorganisms such as $E$. coli should be considered and investigated. In particular, periodic checks on the occurrence of $E$. coli in well and spring waters are important to ensure that effective measures are taken to reduce diseases caused by E. coli.

\section{Acknowledgments}

We thank the Municipal Health Officer Dr. Jojo Lozo for their support on the project/research. We are also grateful to the Angono Mayor Gerardo V. Calderon and the Angono Municipal Council. We are grateful to Kyoto Fission-Track Co., Ltd. for the support provided to our study.

\section{Statement of Authorship}

Kato and Maruyama conceived the idea to measure trace element concentrations in daily life water. Kato, Maruyama, Merino, and Juban collected water samples. Maruyama and Hirata carried out analyses. Maruyama processed analytical data, and wrote the paper. All authors approved the final version submitted.

\section{Author Disclosure}

All authors declared no conflicts of interest.

\section{Funding Source}

This study was partly supported by a Grant-in-Aid for Scientific Research to HK (15K00672, FY 2015-2017) and TH (A26247094, FY 2014-2019) from the Ministry of Education, Culture, Sports, Science and Technology, Japan.

\section{REFERENCES}

1. WHO. Guidelines for drinking-water quality, 4th ed. Geneva, Switzerland: World Health Organization. 2011.

2. Rosborg I, Soni V, Kozisek F. Potentially toxic elements in drinking water in alphabetic order. In: Rosborg I, ed. Drinking water minerals and mineral balance. Switzerland: Springer International Publishing. 2015;79-101.

3. Kapaj S, Peterson H, Liber K, Bhattacharya P. Human health effects from chronic arsenic poisoning - A review. J Environ Sci Health A Tox Hazard Subst Environ Eng. 2006; 41(10):2399-428. doi: 10.1080/10934520600873571

4. Eklund G, Oskarsson A. Exposure of cadmium from infant formulas and weaning food. Food Addit Contam. 1999;16(12):509-19. doi: $10.1080 / 026520399283650$

5. Kordas K, Canfield RL, López, P, Rosado JL, Vargas GG, Cebrian ME, et al. Deficits in cognitive function and achievement in Mexican first-graders with low blood lead concentrations. Environ Res. 2006; 100(3):371-86. doi:10.1016/j.envres.2005.07.007

6. Miranda ML, Kim D, Galeano MA, Paul CJ, Hull AP, Morgan SP. The relationship between early childhood blood lead levels and performance on end-of-grade tests. Environ Health Perspect. 2007; 115(8):1242-7. doi:10.1289/ehp.9994

7. Leggett RW. The behavior and chemical toxicity of $U$ in the kidney: A reassessment. Health Phys. 1989; 57(3):365-83. doi: 10.1097/00004032-198909000-00001

8. Mao Y, Desmeules M, Schaubel D, Berube D, Dyck R, Brule D, et al. Inorganic components of drinking water and microalbuminuria. Environ Res. 1995; 71(2):135-40. doi: 10.1006/enrs.1995.1075

9. Kurttio P, Auvinen A, Salonen L, Saha H, Pekkanen J, Makelainen I, et al. Renal effects of uranium in drinking water. Environ Health Perspect. 2002; 110(4):337-42.

10. Raymond-Whish S, Mayer LP, O’Neal T, Martinez A, Sellers MA, Christian PJ, et al. Drinking water with uranium below the U.S. EPA water standard causes estrogen receptor-dependent responses in female mice. Environ Health Perspect. 2007; 115(12):1711-6. doi:10.1289/ehp. 9910

11. Anderson RA. Chromium, glucose intolerance and diabetes. J Am Coll Nutr. 1998; 17(6):548-55. doi: 10.1080/07315724.1998.10718802

12. Anderson RA. Chromium and diabetes. Nutrition. 1999; 15(9):720-2. doi: 10.1016/S0899-9007(99)00128-8

13. Dattilo AM, Miguel SG. Chromium in health and disease. Nutrition Today 2003; 38(4):121-33.

14. WHO. Chromium in drinking-water. Background document for preparation of WHO Guidelines for drinking-water quality. 2003. Geneva, Switzerland: World Health Organization (WHO/SDE/ WSH/03.04/4). 
15. Maruyama S, Hattori K, Hirata T. Concentrations of uranium and thorium in bottled mineral waters. Chikyukagaku (Geochemistry). 2014; 48(3):187-99 (in Japanese with English abstract and captions). doi: 10.14934/chikyukagaku.48.187

16. McLennan SM. Relationships between the trace element composition of sedimentary rocks and upper continental crust. Geochemistry, Geophysics, Geosystems 2001;2, Paper number 2000GC000109.

17. Hampton CR, Bowen HC, Broadley MR, Hammond JP, Mead A, Payne KA, et al. Cesium toxicity in Arabidopsis. Plant Physiol. 2004; 136(3):3824-37. doi: 10.1104/pp.104.046672

18. Reimann C, Birke M. (Eds.). Maps and their interpretation. In: Geochemistry of European bottled water. Stuttgart, Germany: Borntraeger Science Publishers; 2010. pp. 63-199.

19. Johnson GT, Lewis TR, Wagner WD. Acute toxicity of cesium and rubidium compounds. Toxicol Appl Pharmacol. 1975; 32(2):239-45.

20. Pinsky C, Bose R, Taylor JR, et al. Cesium in mammals: Acute toxicity, organ changes and tissue accumulation. J Environ Sci Health Part A. 1981; 16(5):549-67. doi: 10.1080/10934528109375003

21. Messiha FS. Developmental toxicity of cesium in the mouse. Gen Pharmacol. 1994; 25(3):395-400. doi: 10.1016/0306-3623(94)90186-4

22. Ghosh A, Ghosh AK, Sharma A, Talukder G. Modification of cesium toxicity by calcium in mammalian system. Biol Trace Elem Res. 1991; 31(2):139-45. doi: 10.1007/BF02990422
23. Saito S, Nakano T. Evaluation of water quality of Laguna Lake watersheds. In: Proceedings of the 1st International Symposium on Managing Environmental Risks to Food and Health Security in the Laguna Lake Watersheds, Philippines. June 3, 2011, Kyoto, Japan, pp. 28-30.

24. Kada R. Strategy for survival of food and agriculture. Kyoto, Japan, Showado. 2014. pp. 141 (in Japanese).

25. PSA. Municipality of Angono - Code:045801000 [Internet]. Philippine Standard Geographic Code (PSGC), Philippine Statistics Authority. 2015 [cited 2020 Feb]. Available from https://psa.gov.ph/ classification/psgc/?q=psgc/barangays/045801000

26. Kato H, Maruyama S, Merino GJ, et al. Community-driven evaluation of $\mathrm{E}$. coli levels in domestic use underground water sources in Angono. Acta Med Philipp (forthcoming).

27. Lomboy M, Riego de Dios J, Magtibay B, Quizon R, Molina $\mathrm{V}$, Fadrilan-Camacho V, et al. Updating national standards for drinking-water: a Philippine experience. J Water Health. 2017; 15(2):288-95.

28. US EPA. Technical overview of ecological risk assessment: risk characterization [Internet]. United States Environmental Protection Agency (US EPA). 2017 [cited 2020 Feb]. Available from https://www.epa.gov/pesticide-science-and-assessing-pesticiderisks/technical-overview-ecological-risk-assessment-risk

\title{
Have you read the current trends in
} Medical and Health Research in the Philippines?

\section{Acta Medica Philippina The National Health Science Journal}

\author{
Access Online: www.actamedicaphilippina.upm.edu.ph
}

